\title{
Personality Counselor Perspective Buya Hamka (Study Of Interpretation Of Al-Azhar Verses Advice)
}

\author{
Syariful ${ }^{1}$ \\ ${ }^{1}$ Departement of Bimbangan Konselig Islam, Faculty of Psicologhy and Education, University of Al Azhar \\ Indonesia, Jl. Sisingamangaraja, Kompleks Masjid Agung Al Azhar, Kebayoran Baru, Jakarta Selatan 122110 \\ Penulis untuk Korespondensi/E mail: syariful.ipoel@yahoo.com
}

\begin{abstract}
Talking about the counselor's problem is inseparable from his duty to bring his client to life that is blessed by Allah SWT, and the counselor is able to realize the lifestyle in words, behavior, and mood, so that what the counselor gives to the client provides guidance for the counselor at the same time also become a good practicing in the teachings of Islam. Therefore, it is very important for the counselor to be kind and noble in accordance with what is taught by Islam in the Qur'an and hadith. Hamka as the interpreter of the Qur'an has explained the character and ethics of the counselor. Studying a meaning in the Qur'an certainly requires knowledge and knowledge, and all of that is inseparable from the interpretation of several scholars through the existing interpretive books, one of which examines Hamka's thoughts on the verses that contain the words of advice and irsyad in Tafseer Al-Azhar . Islamic guidance and counseling according to Hamka is a teaching process for someone (client) who does not know or who needs help in a gentle and sincere way to enforce amar ma'ruf and nahi munkar. The character of the counselor according to Hamka in the verses of advice and irsyad, namely: Patient, generous and wise, intelligent, not despairing, not arrogant, humble, compassion and empathy. Whereas counselor ethics according to Hamka in advice verses and irsyad, namely: Openness, religion, amar ma'ruf nahi munkar, and enthusiasm.
\end{abstract}

Keywords - Advice and Irshad, Counselor Personality, Counselor

\section{INTRODUCTION}

$\mathrm{I}$ slam provides guidance to individuals to be able to return to the Qur'an and Sunnah. Islam directs individuals to understand what the tests and calamities mean in life. Anxiety, fear and anxiety are the flowers of life that must be overcome by each individual by pleading His help, through experts, one of them is a counselor. [1] The characteristics of counselors that are the goal of counseling are people who have good relations with God and good relationships with fellow humans and the environment [2].

Advice is part of Islamic da'wah which in practice is used in the guidance and counseling services, the importance of an advice, both for yourself and for others because there is good in it.

Muhammad Saleh al-Munajjid in the book The Smart Ways of the Prophet Saw Correcting the Errors of Others, namely: When we see someone making a mistake, bad, or munkar, we should reprimand, warn, and show the way of truth to him, mistakes or mundane cannot be let alone maintained. However, efforts to correct errors it is not easy, if wrong in responding, the person we admonish may get angry or get away from the truth, [3].

Advice and irsyad method is one method that is very important in counseling, because the lead counsel of a counselor in order to continue to learn and strive to provide good problem solving to help clients, and evaluating services which has been carried out to be used as counsel for personal counselors. The Qur'an guides people to always make the Qur'an as the main way of life of all aspects of life, wrong only aspects of guidance and counseling in the form of advice and irsyad.

In examining a meaning in the Qur'an it certainly requires knowledge and knowledge, and all of that is inseparable from the interpretation of some scholars through the existing books of interpretation.In Indonesia, in particular there is one famous figure, 
he is a commentator (interpreter, one who explains especially the interpreter of the Qur'an) [4]. The author here examines the personality of the counselorin the eyes of Islamic guidance and counseling in his thoughts on the verses which contain the words of advice and irsyad. Author assumed that by understanding all of Hamka's thoughts in his interpretation of the verses which contained the words of advice and irsyad, it was obtained an illustration of how the personality of the Muslim counselor desired by the Qur'an. The personal character of a counselor and a counselor in carrying out the process of guidance and counseling.

Ethics is morality, ethical issues according to Hamka mean talking about good problems and bad problems [5]. Hunainah in his book entitled Ethics of Guidance Professionals Counseling sources of ethics derived from religious teachings adopted by counselors and counselees contained in their respective scriptures, the position of religious teachings as a source of ethical counseling guidance is above other ethical sources. Because the truth of religious teachings is absolute, it comes from the Word of God [6]. The Qur'an and hadith are the main guidelines for Muslims, especially for Muslim counselors in behaving and behaving. The Qur'an is the source of Islamic teachings and a source of guidance, advice, and medicine in addressing various problems [7]. As the word of God Almighty in QS Jonah $10: 57$ :

Meaning: "O people, Truly!, has come to you (AlQur'an) lessons from your Lord, a healer for diseases that are in the chest and guidance and mercy for those who believe." [8].

In the Qur'an, there are many words that can be associated with guidence and counseling include syifa (medicine) mau'izah, irsyad, advice, and so on . Syifa, mau'izah, irsyad, advice is a dimension of Islamic guidance and counseling. The verses that explains about the Qs syifa At-Tawbah 9: 14, Surah As-Syu'ara 26:80, Qs Jonah 10: 57, Qs AnNahl 16: 69, Qs Al-Isra 17: 82, Qs Fussilat 41 : 44. While I want it in $Q s$ An-Nahl 16:125 and $Q s$ Yunus $10: 57$, and Qs Al-Baqarah $2: 275$.

The verses that describe the counsel and the $Q S A l$ Baqa irsyad rah [2]: 186, Surat Al-Baqarah 2: 256,
Surat al-A 'raf 7: 146, Qs Al-Jin 72: 2, Qs An-Nisa 4: 6, Surah Al-Kahf 18: 2, Al-Qs Anbiya '21:51, Surat Al-Kahf 18: 10, Surat Al-Kahf 18: 24, Surah Al-Jinn 72: 10, Surah Al-Jinn 72: 14, Qs Al-Jin 72 : 21, QS Ghafi r 40:29, QS Ghafir 40:38, Qs AlHujurat 49: 7, QS Hud 11: 7 8, QS Hud $11: 87$, QS Hud 11: 97 , Qs Al-Kahf 18: 17, Qs Al-Kahf 18: 66, Qs Al-A 'raf 7:21, 62, 68, 79, and 93, Qs AlQasas 28: 20, QS Hud 11 : 34.

According to the Al-Dictionary Munawwir الإرشاد has the meaning of guidance, awareness, awareness, teaching, guiding, giving advice [9].(Munawir, 1997: 499). According to Fakhruddin, the form of the word irshad, which means guidance, the truth of the teachings, and the guidance of Allah SWT which contains an atmosphere of closeness between the giver (counselor) and recipient (client). In terms of irsyad, it means showing the truth of the teachings, and guiding others in carrying it out which takes place in an atmosphere of a face of face and full of intimacy [10]. According to the Dictionary of Al-Munawwir النصيحة advice, mutual understanding, lots of advice [9]. Providing guidance and counseling services to clients has the value of worship, because in the process of assistance contains the value of upholding amar ma'ruf nahi munkar (inviting goodness and preventing evil), providing services to clients based on sincerity and patience.(Amen, 269). One of the guidance and counseling techniques used is advice and irsyad.

\section{METHOD}

This research uses a literature review method that is understanding the character contest of a counselor in Hamka's view, the researcher is dealing directly with text (numeric) or numerical data and not with direct knowledge from the field or eyewitnesses in the form of events, people or other objects. Library data is 'ready to use' (ready made). This means that researchers do not go anywhere, except only dealing directly with source material that is already available in the library. Library data are generally secondary sources, in the sense that researchers obtain material from second hand and not original data from first hand in the field. The condition of library data is not limited by space and time. Researchers deal with static, fixed information. 


\section{RESULT AND DISCUSSION}

\section{Islamic Counseling And Al-Azhar Tafsir Verses Islamic Counseling According To Hamka}

Counseling in Islam is known as the term (taujih wal irsyad ) [11]. Ershad Islam is a form of Islamic da'wah. The form, of Irshad da'wah Islam epistemologically gave birth to the science of Ershad.Ershad Islam is more directed to the process of internalization and transmission of Islamic teachings in the form of ibda bi al-nafs, zikrullah, prayer, wiqayat al-nafs, tazkiyyat al-nafs, prayer and fasting, taklim, taujih, mau'izhah and nashihah, and isytisyafa, also called the science of Guidance and Islamic Education [12]. Islamic guidance and counseling is the embodiment of Islamic da'wah in the form of Ershad Islam because it is one form of Islamic da'wah, [11] because in its implementation guidance and counseling use many techniques. One technique is advice and teaching ( irsyad).

Hamka in his life was an ulama who always preached to anyone. Hamka called da'wah as quoted by Alwisral in his book Da'wah Strategy in Forming Da'i and Khotib Professional, namely as tabligh, because according to Hamka's words in the past the word dakwah was not yet popular, the use of the word dakwah that was widely used was tabligh. According to Jalaluddin Rakhmat:

"In the context of da'wah, advice is more personal, personal, and four eyes. Advice is counseling that solves and overcomes one's religion. Because each person has a problem that is different from each other, the advisor must be observant in seeing the condition of his client. He needs to learn the methods of guidance and counseling (al-nashihah wa alirsyad ). The counselor must also feel what the client feels. This is what is called hudhuri (involving himself in the experience of others). [13].

\begin{abstract}
Advice according to Hamka in Modern Sufism with citing dictionary author Misbahul Munir stating that advice is defined as 4 cases: Ikhlas, tulus, musyarawah and charity. Ibn Athir said in his Nihayah "the advice is a word that has a long meaning, I want the person who is given the advice to get good". The sincerity according to Hamka means that there is no clean up . Advice to the Muslims according to him:
\end{abstract}

"If you are a fool, study with the smart, if you are a clever person, teach the fool. Show the benefit of the salvation of the world and the hereafter, do not hurt them with their hands or with their tongues, close their shame and blasphemy, help those who are hungry if you are able, avoid the danger of them, find benefits for them, ask to do good, forbid evil, it is gentle and sincere. " [14].

Of the two notions of advice according to Hamka above, it can be concluded that the notion of Islamic guidance and counseling according to Hamka is the process of teaching to someone (client) who does not know or who needs help with a gentle and sincere way to uphold amar ma'ruf and nahi munkar .

\section{Counselor Character According to Hamka}

Islam has many figures that can be used as examples for all of us. One of our uswatun hasanah figures (a good example) is the Prophet Muhammad. His noble character and amazing personality whoever is near him will feel comfortable. He is a guide for his family, his friends and his people to the path of Allah SWT. The Qur'an has explained that the Prophet Muhammad SAW is a role model for all.Prophet Muhammad SAW carried out his duties as a Prophet and Apostle which taught what we did not know. This has been explained in QS Al-Ahzab 33: 21 which means:

"Indeed, there is already in the Messenger of Allah a good example for you, that is for the one who expects Allah's grace and the coming of the Day of Judgment and he calls Allah a lot."

The task was not only carried out by the Prophet Muhammad SAW, but also the other Prophets guided their people to the right path. The character of the Prophets has been explained in the Qur'an, in this study the author will explain the character of the Prophets in guiding their people. Among them the characters of the Prophets that the writer will explain are the Prophet Shu'aib, the Prophet Khidr, Noah, and Moses. Asmuni quoted Hamka's statement in the Principle and Wisdom of Islamic Da'wah, which is the primary means of da'wah morals. (Asmuni, 1993). Below the character of the counselor will be explained accordingly Hamka:

\section{Patient, Chest and Wise Field}

Hamka interpreted the meaning of the word irsyad (الرَّثُشيدُ) in QS Hud 11 : 8733 which is wise. Prophet Syu 'disgrace as a guide for his people. Before he conveyed the noble duty of Prophet Shu 'disgrace to strengthen his soul with worship (prayer). As Hamka said: "Apparently long before he delivered the message of Allah's command, he had strengthened the soul 
by praying in his own way, different from praying with them. And in the story of the Prophet Shu'aib, he has got the impression that it is for strengthen the task soul , the first and foremost tool is prayer." [15].

And in the last verse Hamka conveyed: "He has received appreciation from his people so far that he is a good person, patient, roomy, and wise. The Prophet Shu'aib has been acknowledged by his people as a person who is open-hearted, forgiving and very wise, because that is the way he has been. But as a messenger of God he is must convey the word truth, even though it is bitter. Undoubtedly because of the bitter words he delivered, his people were angry. They may withdraw their confession and this is the result of people who want to come forward leading the people to the right path. He must not be silent, just because he maintains the praise he received so far. He is obliged to continue his work, even though he will be scolded."

In this verse the praise of his people for the Prophet Shu'aib, said a patient, roomy, forgiving, and wise, may also be said to be a compliment of deception. The story of a figure of the Prophet Shu'aib with his people is an important teaching for everyone who wants to guide him to the right path. [16].

Hamka revealed in his book Personal Great : "The emergence of a wise attitude is due to knowledge, determination, and because of putting things in place. A wise person is right in his opinion, far from his view and good interpretation. Wisdom is the main joint of life in establishing a high quality person. From there it grows morally as the foundation of life's virtue. Wisdom of wisdom is a special gift from Allah SWT to His servants. Allah SWT gives wisdom to anyone who is desired. Whoever is endowed with wisdom will gain a lot of grace [15].

So, the character of the Prophet Syu'aib who is patient, graceful and prudent provides an example for a counselor that when carrying out the process of guidance and counseling it is necessary to have patience, be patient and wise. Patience when providing guidance and counseling services, patiently face client problems. Through the patience of the counselor in the counseling process can help clients todevelop itself naturally. Patience shows that the counselor shows more attention to the client than the results and patience also tends to display the qualities of attitudes and behavior that are not difficult. [17]. Likewise, openly accepting his client's background and wise when deciding the solution to the problem faced by the client.

\section{Smart}

In Qs Al-Kahf (18): 6639, Hamka interpreted the word irsyad رُشْثْدًا (taught to you". According to Hamka the Prophet Musa tried to find a teacher whose characteristics Allah Almighty had shown namely in the previous verse. And sure enough just saw that person the first time, Moses knew that it was the person who was told to Allah is looking for him. We do not wonder if it is immediatelyMoses admonished him respectfully and said to people this is the Prophet Khidr. As Hamka stated: "A question that is arranged in such a way that shows that Moses after providing himself as a disciple and acknowledging before the teacher that many things he did not understand. Hopefully the knowledge of the teacher is explained to him, until he understands as a faithful student [16].

\section{Does not break Asa}

The word of advice ( نُصنجِ ) in QS Hud (11): 3442, Hamka interprets "My Advice". According to Hamka the advice given by the Prophet Noah to his people did not contain a sense of despair, but a sense of duty awareness. Noah must continue his call, as the Messenger of Allāh W conveyed his advice as his duty as an Apostle. Although his advice is often rejected by his people, it does not make him stop, because Allah forbids him to stop. and ( أَنْصَحَح ) "I want to give advice". If God wants to lead them astray, because of their own mistakes, nothing can hinder them. Therefore, he also reminded him: " He is your Lord!" He is the Almighty who determines your destiny, not me: "And to Him you will all return." [16].

From the explanation according to Hamka above, Noah's figure can be used as an example that being a guide should not be discouraged by any situation with the client who will be guided. And the counselor must also realize and carry out the noble task with all his heart. Because anyone who is sincere in his effort to find the truth, is always patient and not discouraged, then Allah will show him the way.Goodness will be obtained not only in the world, but also in the here after [15].

Hamka also stated: "There are two things that weaken the spirit of prejudice and rotten heart. Why is prejudice, because prejudice narrows the soul and the rotten heart of being insulting, ridiculing, sneering at others. "Hamka's advice is to be passionate and not to despair if the words he says are 
conscience. When writing, what he wrote was the voice of the soul. The word heart is accepted by the heart, the voice of the soul is welcomed by the soul too. Words that are not really only will arrive at the leaves of Teli Nga not enter the heart [15]

For this reason a counselor is always optimistic with every problem faced and helps ease the burden on his client.

\section{No Sow}

Hamka gives an understanding in Qs Al-A'rf (7):

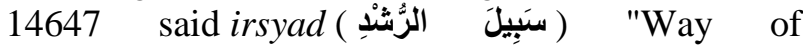
guidance". The way of guidance for Pharaoh, because Fir'awn chose the wrong path compared to the right path, that is Allah, the Almighty had given the correct way of direction through the prophet Moses. In this verse is also a warning to the people of the Prophet Moses and also a warning for us. That makes Pharaoh do not want to choose the right path because of the arrogant nature that resides in him. Takabur according to Hamka means "selfrearing (self-forgetfulness). Feel the greatest, even though there is no more than a creature that crept on this earth. people who are arrogant cause they cannot accept truth and advice. Being arrogant is the devil's demon. "As a result of his arrogant nature, Fir'awn himself and his great man had sunk in the ocean. moral causes the destruction of Pharaoh was warned again. Because arousal can be a disease. If humans are arrogant, God will turn them away from His verse. " And if they see each verse, they do not want to believe to her. "That is the result of infertility. So many verses of Allah, as a warning to Pharaoh, but he also did not want to change his attitude because of being arrogant. "That is the case, because they have denied the verse We and those of them are negligent. But they are looking for reasons to choose to pray their prayers [16].

From the above verse it can be an example that the nature of the arrogant is a trait that will destroy itself especially for a guide, because the verse above is a warning for all of us not only Pharaoh (his client Prophet Musa). As the obedience of Hamka "the person who arouses causes not being able to accept and advice". For this reason a counselor is careful not to be arrogant to the client, fellow counselors, because being arrogant indicates that he feels better than others. And it is not appropriate for a counselor to give advice and teaching to others to be arrogant.

\section{Humility}

Hamka interpreted the word irsyad (وَلا رَشًَْاً) in this verse, "Nor can it be good". I according to Hamka in this verse is the Prophet Muhammad. The Prophet Muhammad SAW had no power to reduce harm to his people or to give goodness. Because everything is a matter of Allah SWT alone. However he was challenged to show power but he admitted frankly that he was a human being as people he arrived and he claimed it too. Said Muhammad: "You must not oppose me asking for provisions, because I have no power, either to bring harm to you or to defend you. Whereas myself cannot refuse if Allah SWT wants something for me. "Hamka explained the humble figure of the Prophet Muhammad SAW, that he did not have the power to reduce poverty and benefit his people. He is the same man as mad'unya. Do not feel having the strength among the people who oppose it, except if Allah SWT has wanted and ordered the Prophet Muhammad to show the advantages. Only the Prophet Muhmmad SAW showed the people who opposed it. As Hamka said above. Even a mentor can model the nature of the Prophet Muhammad SAW that is humble with the advantages he has. As Hamka advises that:

"Humility (tawadhu ') is aware of our true position so it is not arrogant and not inferior. a person who raises himself more than he should, enlarges himself, is not honest, surely in the near future will appear his ignorance or weakness. Because people who are good at adjusting are those who know their position. He knows his strengths and weaknesses [15]. And people who can adjust themselves will certainly be respected, interviewed, and liked by others.

And a good counselor will act tawadhu 'towards others, especially to the client who is guided by him, aware of the limitations he has and does not feel that he is a great counselor but a counselor who continues to learn and improve himself.

\section{Compassion and Empathy}

The word of advice (النَّاصِحِينَ) in this verse Hamka means "people who give advice". Hamka said: "A man advising the Prophet Musa is very likely that the person came suddenly, or that day. He came to Moses to bring the news in haste, because it was very important, then he said: "O Moses! "Indeed, the authorities of the country are negotiating about you to kill you." Perhaps the talk of the murder took place yesterday. Moses had dared to kill one of the Qubthis (the closest family from the palace), from the Pharaohs themselves. Maybe this is the child 
who was hinted by the sorcerer so far, will undermine the power of the King. This is a plot! This is a dangerous attitude! Moses had shown an attitude, namely defending the Children of Israel. Though all this time his life was raised, cared for and educated by the palace.

In the negotiations before this danger spreads, soon Moses was killed! so that the movement of the Israelites against the Qubthis (the Kings) was exhausted before it spread and grew! The discussion was heard by the man. The man who seems to have compassion and empathy for Prophet Musa as soon as possible, he seeks the Prophet Moses before anyone acts. Therefore, the man rushed. Get him first to tell Moses, and Moses immediately departs before he is captured or killed . Then came out $\mathrm{N}$ abi Musa as soon and ran away. " [15].

From the story of Prophet Moses with someone who delivered the news above, namely someone who believes acts as a counselor and the Prophet Moses is informed of the news (client). So when someone gets bad news about our brother who will endanger his life, our obligation to convey the news is that our brother will be careful and save. A mentor must have the nature of affection and emotion for his client, such as the story of the believer who shows his affection and empathy for Prophet Moses.

\section{As Hamka revealed:}

"Men who seem to have compassion and empathy for Prophet Musa as soon as possible he is looking for Prophet Musa before people act. Therefore, the man rushed. Get him first to tell Moses, and Moses immediately departs before he is captured or killed. Then Prophet Musa came out and ran away! " Hamka revealed that empathy arises because of a shining heart. The light shone in the eye so that the facial expression became clear. " [15].

The Prophet Muhammad SAW has exemplified that empathy is not just a feeling of client suffering, but more applicable, as if the client is not alone in the problem. " [11]. Good, pure-hearted counselors will certainly be able to appreciate the feelings of others by learning to empathize with the feelings of clients. When a counselor is interacting with a client, the counselor learns to understand the client's feelings by empathy. And Counseling is a form of affection, if someone advises others, it means that the attitude indirectly reflects affection, therefore, the counselor loves the client by giving him advice and helping the client's difficulties

\section{CONCLUSION}

Based on the discussion and analysis of the object of research, namely the character and ethics of counselors according to Hamka in the interpretation of the verses of advice and irsadad described above and at the same time as an answer to the formulation of the problem in this study, the authors can conclude a few points below:

1. Islamic guidance and counseling according to Hamka is a teaching process to someone (client) who does not know or who needs help with a gentle and sincere way to uphold amar ma'ruf and nahi munkar.

2. The character in the sphere of Islamic personality psychology is called akhlak ( $a l$ Khuluq ), that is the condition in the holy soul, it can also be interpreted as character, temperament, unique nature, a continuous and familiar nature that can be used as a character to identify a person personal. The counselor according to Hamka in the verse verse of advice and irsyad, namely: patient, graceful and wise, intelligent, not despairing, not arrogant, humble, compassion and empathy.

3. Ethics according to Hamka is talking about good and bad problems. while counselor ethics according to Hamka contained in the verses of advice and irsyad, namely: openness, religious, amar Ma'ruf Nahimunkar

\section{REFERENCE}

[1] H. B. Adz-Dzaky, Islamic Counseling and Psychotherapy, Yogyakarta: Fajar Baru Library, 2004.

[2] S. M. Amin, Guidance and Islamic Counseling, Jakarta: Amzah, 2010.

[3] S. M. S. Al-Munajjid, The Smart Way of the Prophet Saw Correcting Others' Errors, Jakarta: Period, 2010.

[4] S. Wojowasito, Dictionary of Indonesian Language, Malang: CV Author, 1999.

[5] A. Haris, Hamka Ethics, Yogyakarta: LKIS, 2010.

[6] Hunainah, Professional Ethics of Counseling Guidance, Bandung: Rizqi Press, 2013.

[7] Erhamwilda, Islamic Counseling, Yogyakarta: Graha Ilmu, 2009.

[8] Departement of Religion RI Bandung, Al Qur'an and Translation, Bandung: PT sygma Examedia Arkanleema, 2009. 
[9] Munawir, Complate Al-Munawir Arabic Indonesian Dictionary, Surabaya: Progressif Library, 1997.

[10] Enjang, Communication Counseling, Bandung: Nuance, 2009.

[11] M. Syarif, Islamic Guidance and Counseling Source to Patients, Jakarta: Ministry of Religion, 2012.

[12] I. Z. Arifin, Bimbingan Islamic Counseling Development of Da'awah Through Islamic Psycotherapy, Jakarta: Rajawali Press, 2009.

[13] M. A. Aziz, Da'wah Science, Jakarta: Kencana, 2009.
[14] I. Hamka, Father, Jakarta: Republika Press, 2013.

[15] Hamka, Great Person, Jakarta: Gema Insani, 2014.

[16] Hamka, Tafsir Al Azhar, Juz XI-XII-XIIIXIV-XV-XVI, Jakarta: Pustaka Panjimas, 2000.

[17] S. Yusuf and A. J. Nurihsan, Basis of Guidance and Counseling, Bandung : PT Remaja Rosdakarya, 2010. 